\title{
Conselho Nacional de Justiça: Desenho Institucional, Construção de Agenda e Processo Decisório*
}

\section{Roberto Fragale Filho}

Professor titular do Programa de Pós-Graduação em Sociologia e Direito, da Universidade Federal Fluminense (UFF), Rio de Janeiro, Brasil

\footnotetext{
$\mathrm{O}$
} governo da Justiça era, sem dúvida, uma das principais questões envolvidas no debate da Reforma do Judiciário, cujo resultado consistiu na criação do Conselho Nacional de Justiça (CNJ). Com ele, assumia-se estar introduzindo uma dimensão específica de controle social cujas possibilidades contrastavam com o anterior modelo de um poder judiciário fragmentado, pulverizado em ilhas e reticente à construção de pontes. Em outras palavras, apresentava-se um remédio constitucional para um judiciário que teria permanecido opaco e inacessível, que não vivenciou a grande promessa constitucional de supe-

\footnotetext{
* A primeira versão deste artigo, originalmente denominado "O Conselho Nacional de Justiça e seus possíveis impactos institucionais", foi apresentada, em setembro de 2011, em um seminário interno da Fundação Getulio Vargas (FGV-Rio). Os comentários efetuados pelos colegas Diego Werneck Arguelhes, Fernando de Castro Fontainha, Marcio Grandchamp e Tânia Abrão Rangel foram substancialmente importantes para sua apresentação, em outubro de 2011, no 35ํㅡㄹ Encontro Anual da Associação Nacional de Pós-Graduação e Pesquisa em Ciências Sociais (Anpocs). Os comentários então efetuados pela debatedora Maria Inês Bergoglio e pelos colegas Andrei Koerner, Ernani Rodrigues de Carvalho Neto, Fabiano Engelmann e Marcos Faro de Castro em muito contribuíram para uma segunda versão, que veio a ser apresentada no $8^{\circ}$ Encontro da Associação Brasileira de Ciência Política (ABCP), já com uma relevante modificação de boa parte de seu argumento. Esta terceira versão é, portanto, tributária de novas contribuições, em especial aquelas efetuadas pelo debatedor Maurício Moya no 8oㅡㄹ Encontro da ABCP e, posteriormente, pelos pareceristas anônimos de Dados. Com todos eles, comentaristas de todas as etapas de sua elaboração, compartilho as qualidades do texto, reservando para mim seus eventuais defeitos.
}

DADOS - Revista de Ciências Sociais, Rio de Janeiro, vol. 56, no-4, 2013, pp. 975 a 1007. 
ração do déficit democrático em todos os seus sentidos: político, econômico e social. Assim, uma otimista avaliação de sua atuação ao longo de suas três primeiras gestões indicaria que "a redoma sofreu fraturas, (pois) foi rompida a inércia e enfrentados tabus" (Sadek, 2010). Este diagnóstico pode, entretanto, ser pertinentemente contestado na medida em que se sustente, por um lado, que as fraturas não alteraram sua opacidade (ainda que tenham lhe dado maior visibilidade) e, por outro lado, que elas não possibilitaram o desenvolvimento de um controle efetivamente externo no governo da Justiça (ainda que tenham ampliado a arena do debate).

$\mathrm{Na}$ verdade, conquanto sua maior visibilidade possa ter ampliado as possibilidades de uma crítica externa, a demanda por um controle social externo foi reiteradamente derrotada, nas últimas quase três décadas, em todos os debates sobre o governo da Justiça. Recusada na constituinte, ela foi ressuscitada na Reforma do Judiciário, que a incorporou em um desenho institucional pautado por um conselho predominantemente preenchido por profissionais do aparato judicial. Ainda assim, a resistência não foi pequena e deu-lhe voz a Associação dos Magistrados Brasileiros (AMB) ao propugnar por sua inconstitucionalidade (ADI no3.367-DF) em virtude de pretensa ofensa ao princípio da separação de poderes. Por sua vez, ao afastar a alegada ofensa e reconhecer sua constitucionalidade, o Supremo Tribunal Federal (STF) oferecia uma vitória de Pirro, já que seu principal argumento assentava que o Conselho não representava um órgão externo, mas encontrava-se integrado ao Poder Judiciário. Em outras palavras, o Conselho representava, tão somente, uma mudança de arquitetura institucional, cuja nova configuração proporcionava uma "ligeira abertura" do Judiciário à sociedade ${ }^{1}$, supostamente mais adequada para que ele oferecesse respostas aos seus problemas, que, contudo, não pareciam dizer respeito ao seu déficit democrático. Escamoteava-se, dessa forma, a demanda por uma mais ampla accountability ${ }^{2}$, que incluísse uma dimensão externa de controle no aparato judicial.

\section{DESENHO INSTITUCIONAL: O CONTROLE SOCIAL DO JUDICIÁRIO}

No debate substantivo relacionado com o governo da Justiça, independência e accountability são, sem dúvida, seus dois fundamentais e antagônicos aspectos (Garoupa, 2011:31-40). Como encontrar o adequado equilíbrio entre essas duas dimensões é a pergunta forte do governo da Justiça. As respostas fracas ${ }^{3}$ oferecidas têm enfatizado, de uma banda, 
a independência judicial, conduzindo-a a patamares extremos, cuja melhor tradução encontra-se na tradição solipsista inscrita na equivocada ideia de que o juiz não presta contas a ninguém salvo sua própria consciência (Streck, 2010), e, de outra banda, a radicalização da accountability, que sujeita as decisões judiciais aos influxos dos interesses e das conveniências de ocasião na medida em que lhe impõe um perverso e extremo escrutínio. Outras respostas fracas enfatizam uma ou algumas das quatro diferentes dimensões constitutivas destes dois aspectos (Quadro 1).

Quadro 1

Dimensões Constitutivas da Independência e Accountability Judiciais

\begin{tabular}{|l|l|l|}
\hline Dimensão & \multicolumn{1}{|c|}{ Independência } & \multicolumn{1}{|c|}{ Accountability } \\
\hline Pessoal & $\begin{array}{l}\text { Capacidade de decidir de forma } \\
\text { imparcial. }\end{array}$ & $\begin{array}{l}\text { Possibilidade de o juiz } \\
\text { responder pelas suas decisões. }\end{array}$ \\
\hline Coletiva & $\begin{array}{l}\text { Capacidade do poder de não } \\
\text { estar sujeito aos restantes } \\
\text { poderes. }\end{array}$ & $\begin{array}{l}\text { Possibilidade de prestação de } \\
\text { contas aos restantes poderes em } \\
\text { um contexto de democracia } \\
\text { responsável. }\end{array}$ \\
\hline Processual & $\begin{array}{l}\text { Capacidade de melhor gerir as } \\
\text { variadas fases processuais. }\end{array}$ & $\begin{array}{l}\text { Possibilidade de responder por } \\
\text { suas escolhas, incluindo a } \\
\text { congestão dos tribunais. }\end{array}$ \\
\hline Administrativaa & $\begin{array}{l}\text { Capacidade de gerir os recursos } \\
\text { da Justiça sem interferência do } \\
\text { poder político. }\end{array}$ & $\begin{array}{l}\text { Possibilidade de responder } \\
\text { pelos recursos consumidos e } \\
\text { desperdiçados pela Justiça. }\end{array}$ \\
\hline
\end{tabular}

Fonte: Garoupa (2011:34-35).

Em outras palavras, elas preocupam-se prioritariamente com alguma de suas quatro dimensões: pessoal, coletiva, processual ou administrativa e, nesse sentido, produzem respostas insuficientes para os desafios do governo da Justiça. Quando seu enfoque é primordialmente pessoal, tem-se uma "militarização" do aparato judicial, que termina por concentrar poder em suas cúpulas. Quando ele descamba para a dimensão coletiva, tem-se um insulamento, que reduz as possibilidades de desenvolvimento de um efetivo sistema de checks and balances. Quando, por outro lado, seu ângulo preferencial é processual, sua ação volta-se para as questões relativas ao acesso e à morosidade judicial ${ }^{4}$. Quando, por fim, ele se concentra sobre a perspectiva administrativa, termina-se por ignorar a atividade-fim - fazer justiça - para privilegiar a atividade-meio: como otimizar os recursos da justiça? Encontrar um ponto de equilíbrio é, portanto, a pergunta forte a ser enfrentada, e 
uma porta de entrada para se pensarem as possíveis respostas consiste em examinar sua composição e sua competência.

\section{COMPOSIÇÃO: CAPTURAS CORPORATIVAS}

Oriundos de diferentes áreas, os conselheiros são indicados por múltiplos órgãos. O STF, cujo presidente é membro nato e também exerce sua presidência, indica dois outros membros - um desembargador e um juiz - vinculados aos tribunais de Justiça. Por sua vez, o Superior Tribunal de Justiça (STJ) indica um dos seus ministros para ocupar a Corregedoria Nacional de Justiça, além de dois outros membros - um desembargador e um juiz - vinculados à Justiça Federal. Os três membros oriundos da Justiça do Trabalho - um ministro, um desembargador e um juiz - são indicados pelo Tribunal Superior do Trabalho (TST). A Procuradoria Geral da República (PGR) indica os dois membros vinculados ao Ministério Público, sendo um federal e outro estadual. A advocacia encontra-se representada por dois membros, cuja indicação é realizada pelo Conselho Federal da Ordem dos Advogados do Brasil $(\mathrm{OAB})$ e, por fim, a sociedade civil estaria representada pelos dois últimos membros, cuja indicação é realizada, respectivamente, pela Câmara dos Deputados e pelo Senado Federal, observada a exigência de notável saber jurídico e reputação ilibada. Essa diversidade de origem de indicações produz diferentes estratégias por segmento, as quais merecem um exame mais detalhado, que deve tomar por base as diferentes composições do Conselho indicadas no Quadro 2.

Entre os oitos indicados pelo STF, é curioso observar que, em três biênios, reproduziu-se a combinação entre os Tribunais de Justiça dos Estados de São Paulo e Rio de Janeiro (TJ-SP e TJ-RJ). Essa lógica foi rompida apenas no biênio 2009-2010, quando os indicados eram dos Tribunais de Justiça dos Estados de Minas Gerais e Pará (TJ-MG e TJ-PA). É interessante ainda observar que os dois últimos indicados oriundos da magistratura estadual de primeiro grau tiveram uma experiência prévia como juízes auxiliares do CNJ. Com efeito, o ex-conselheiro Paulo de Tarso Tamburini (2009-2011) foi juiz auxiliar da Corregedoria Nacional de Justiça (2005-2006) e da Presidência (2008-2009) e o conselheiro José Guilherme Vasi Werner (2011-2013) foi juiz auxiliar da Presidência do STF e secretário-geral adjunto do CNJ (2010) ${ }^{5}$. Em outras palavras, a existência de uma trajetória prévia no STF ou no próprio CNJ parece funcionar como um elemento qualificador para o exercício futuro da função de conselheiro. 
Conselho Nacional de Justiça

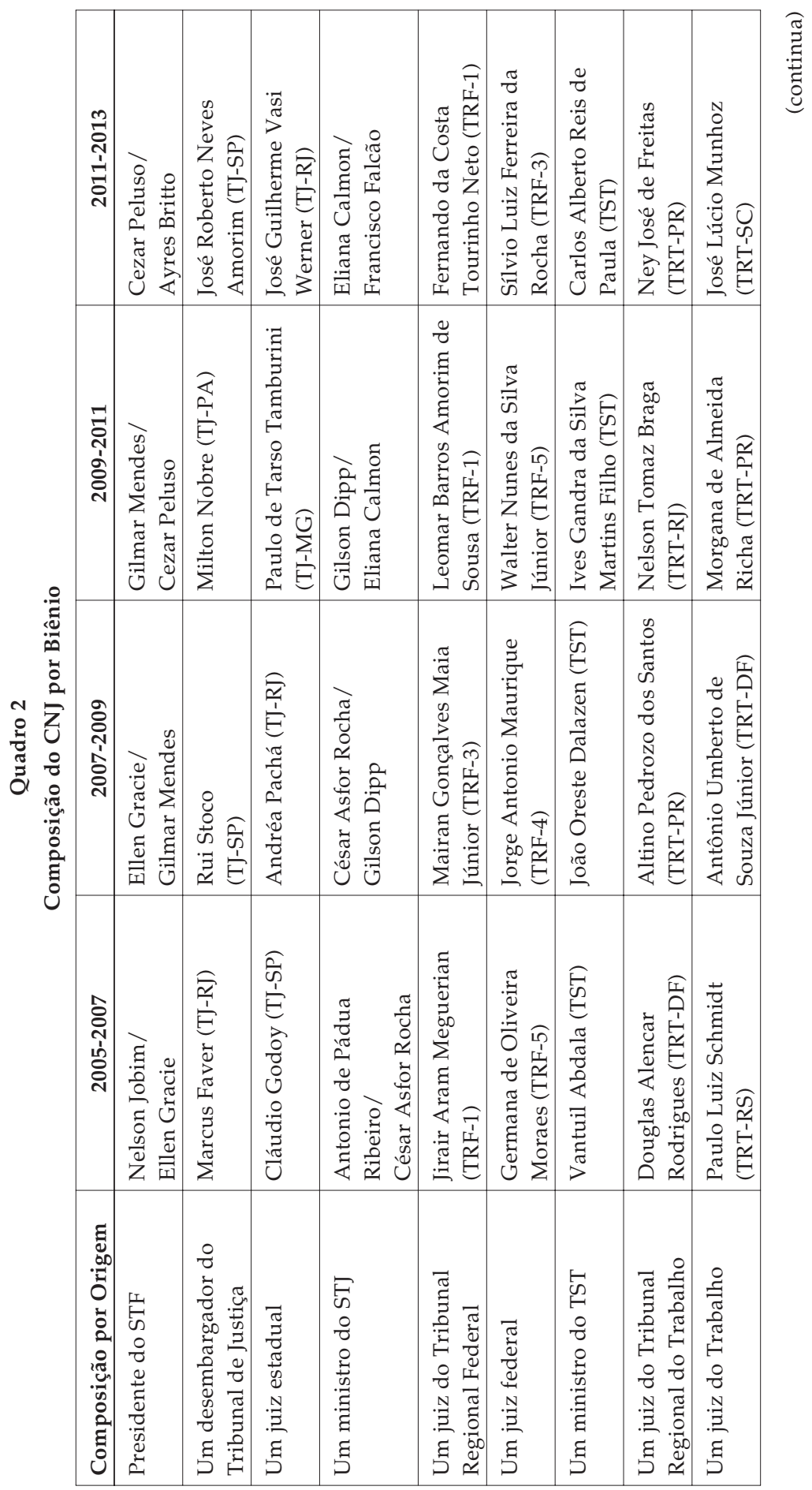

DADOS - Revista de Ciências Sociais, Rio de Janeiro, vol. 56, nํำ 2013 
Roberto Fragale Filho

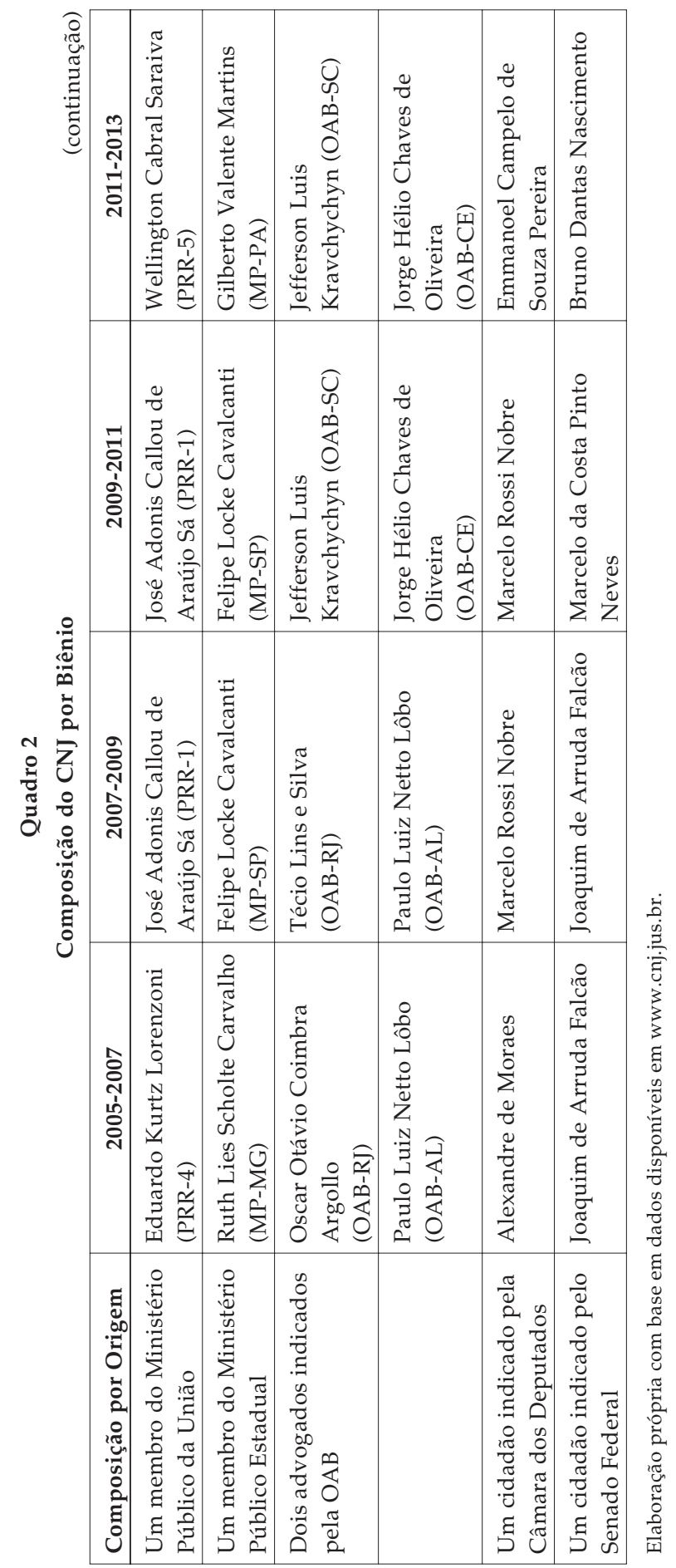

980 DADOS - Revista de Ciências Sociais, Rio de Janeiro, vol. 56, no 4, 2013 
Outra possibilidade de qualificação parece estar presente na existência de uma atuação prévia no movimento associativo da magistratura. Esse indício, embora presente na trajetória da ex-conselheira Andréa Pachá (2007-2009), que foi secretária-geral e vice-presidente da Associação de Magistrados do Estado do Rio de Janeiro (Amaerj), além de diretora de Direitos Humanos (2002-2004) e vice-presidente de Comunicação Social (2005-2007) da $\mathrm{AMB}^{6}$, revela-se mais forte entre os conselheiros oriundos da Justiça Federal. Assim, entre os indicados pelo STJ, nos últimos três biênios, sempre houve um antigo presidente da Associação dos Juízes Federais do Brasil (Ajufe): Jorge Antonio Maurique (2007-2009) e Walter Nunes da Silva Júnior (2009-2011) comandaram a Ajufe, respectivamente, entre 2004-2006 e 2006-2008. Ou seja, suas indicações para o CNJ ocorrem na sequência de suas gestões à frente do movimento associativo. Esse padrão sofre uma ligeira alteração com a indicação do conselheiro Fernando da Costa Tourinho Neto (2011-2013), cuja gestão na Ajufe remonta aos anos 1998-20007. De qualquer sorte, as similitudes entre as três trajetórias indicam que o exercício da liderança junto ao movimento associativo alavanca as pretensões de atuação junto ao CNJ. Quando examinada a origem funcional dos membros oriundos da Justiça Federal, constata-se que o Tribunal Regional Federal da Primeira Região (TRF-1), cuja jurisdição é a maior do país ${ }^{8}$, esteve representado em três biênios, enquanto o Tribunal Regional Federal da Segunda Região (TRF-2), que engloba tão somente os Estados do Rio de Janeiro e do Espírito Santo, nunca teve um único indicado.

Essa mesma aproximação com o movimento associativo é tencionada de forma completamente distinta na Justiça do Trabalho, ainda que na primeira composição do CNJ (2005-2007) ambos os conselheiros indicados pelo TST possuíssem um vínculo anterior com o movimento associativo. Com efeito, Douglas Alencar Rodrigues tinha sido presidente da Associação dos Magistrados da Justiça do Trabalho da Décima Região (Amatra- $X$ ) em dois biênios, além de vice-presidente da Associação Nacional dos Magistrados da Justiça do Trabalho (Anamatra) em 1997-1999, enquanto Paulo Luiz Schmidt, quando indicado para o CNJ, exercia a presidência da Associação dos Magistrados da Justiça do Trabalho da Quarta Região (Amatra-IV) e a vice-presidência da Anamatra ${ }^{9}$. Essa circunstância talvez tenha induzido a Anamatra a conceber um sistema de consulta à magistratura trabalhista no mesmo formato de seu processo eleitoral para sugerir nomes para a representação da Justiça do Trabalho no CNJ. Assim, os candidatos mais vota- 
dos terminam por compor duas listas tríplices - respectivamente, para as vagas de primeiro grau e segundo grau - que são encaminhadas ao TST para análise, já que este é o responsável constitucional pelas referidas indicações.

Tabela 1

Comparação da Indicação do Segundo Grau da Justiça do Trabalho

Anamatra e TST

\begin{tabular}{l|c|c|c|c}
\hline \multirow{2}{*}{ Ano } & \multicolumn{2}{|c|}{ Candidatos } & \multicolumn{2}{c}{ Indicados TST } \\
\cline { 2 - 5 } & $\mathbf{1}^{\mathbf{0}}$ grau & $\mathbf{2}^{\mathbf{0}}$ grau & $\mathbf{1}^{\mathbf{0}}$ grau & $\mathbf{2}^{\mathbf{0}}$ grau \\
\hline 2007 & 13 & 5 & 1 & 0 \\
2009 & 14 & 3 & 0 & 0 \\
2011 & 6 & 3 & 0 & 0 \\
\hline
\end{tabular}

Elaboração própria com base em notícias publicadas na página da Anamatra ${ }^{10}$.

O exame da Tabela 1 evidencia que o TST nunca ratificou para a vaga de segundo grau nenhum dos nomes escolhidos para compor a lista tríplice por meio da consulta eleitoral da Anamatra, o que, entretanto, ocorreu uma única vez para a vaga da magistratura de primeiro grau. Com efeito, em 2007, foi indicado o juiz Antônio Umberto de Souza Júnior, que figurava na lista tríplice encaminhada pela Anamatra, na qualidade de terceiro mais votado na consulta eleitoral. Por outro lado, o exame da tabela permite ainda constatar que a tentativa de "captura" do processo de indicação pelo movimento associativo não obteve êxito. Nesse sentido, verifica-se que o processo eleitoral para o segundo grau foi esvaziado ao longo das três consultas, com as duas últimas apresentando um número de candidaturas equivalente ao número de vagas disponíveis para compor a lista tríplice. Semelhante esvaziamento ocorreu na competição relativa ao primeiro grau, que conheceu praticamente o mesmo número de candidatos nas duas primeiras edições (13 em 2007 e 14 em 2009), mas viu esse mesmo número ser reduzido a menos da metade na última consulta (seis em 2011). Possivelmente, o esvaziamento não se deu na mesma velocidade por conta da indicação do juiz Antônio Umberto de Souza Júnior pelo TST em 2007.

A grande vitória do processo eleitoral concebido pela Anamatra consistiu na adoção de semelhante modelo pelo TST, uma vez que o tribunal encampou um procedimento de inscrição voluntária dos interessados para as indicações de 2009 e 2011. O contraste é flagrante: enquanto a última consulta eleitoral da Anamatra teve nove candidatos para for- 
mar duas listas tríplices (sendo uma delas sem qualquer competição), o TST recebeu 52 candidaturas, das quais 32 eram para o primeiro grau (27 juízes titulares e cinco juízes substitutos) e as 20 remanescentes para o segundo grau ${ }^{11}$. Assim, ainda que o último representante escolhido para o primeiro grau, conselheiro José Lúcio Munhoz (2011-2013), tenha uma trajetória de participação no movimento associativo, pois ele foi presidente da Associação dos Magistrados da Justiça do Trabalho da Segunda Região (Amatra-II) [2004-2006] e vice-presidente da AMB [2008-2010 ${ }^{12}$, essa via de qualificação das candidaturas restou certamente esvaziada pelo TST.

Os dois membros oriundos do Ministério Público são indicados pelo Procurador Geral da República, devendo ser um oriundo do Ministério Público da União (MPU) e outro do Ministério Público Estadual (MPE). É difícil mapear uma estratégia específica de provimento, até porque o debate aqui diz respeito à ausência de rotatividade da representação do MPU, uma vez que os indicados eram todos do Ministério Público Federal (MPF). Nunca foram indicados quaisquer membros dos Ministérios Públicos do Trabalho (MPT), Militar (MPM) ou do Distrito Federal e dos Territórios (MPDFT). Nesse sentido, aliás, são as reivindicações da Associação Nacional dos Procuradores do Trabalho (ANPT), da Associação Nacional do Ministério Público Militar (ANPMT) e da Associação do Ministério Público do Distrito Federal e dos Territórios (AMDFT), às quais se contrapõe a Associação Nacional dos Procuradores da República (ANPR). Esse debate já foi travado no Conselho Nacional do Ministério Público (CNMP), que, em maio de 2009, rejeitou proposta de resolução estabelecendo o pretendido rodízio $^{13}$. Assim, em 2011, a vaga foi mais uma vez preenchida por um membro do MPF, dessa vez com um rodízio entre as procuradorias regionais.

As vagas destinadas à advocacia são preenchidas pelo Conselho Federal da $\mathrm{OAB}$ e elas são marcadas por outra característica: a recondução. Ao longo dos quatro biênios, três indicados foram reconduzidos ao CNJ: os advogados Paulo Luiz Netto Lôbo (OAB-AL), Jefferson Luis Kravchychyn (OAB-SC) e Jorge Hélio Chaves de Oliveira (OAB-CE). Esse padrão é, aliás, também observado nas vagas da advocacia no CNMP, já que os conselheiros foram sempre reconduzidos: Sérgio Frazão do Couto (OAB-PA) e Francisco Ernando Uchoa Lima (OAB-CE), ambos nos biênios 2005-2007 e 2007-2009, além de Almino Afonso Fer- 
nandes (OAB / MT) e Adilson Gurgel de Castro (OAB/RN), nos biênios 2009-2011 e 2011-2013. Ou seja, a única nota dissonante é o conselheiro Oscar Otávio Coimbra Argollo, que certamente não foi reconduzido por conta da mudança política havida na Seccional do Rio de Janeiro com a eleição da chapa de oposição capitaneada por Wadih Damous em 2006. Ainda assim, sua vaga permaneceu com um membro da Seccional fluminense, o advogado Técio Lins e Silva, o que, de certa forma, reproduz a lógica da recondução.

A possibilidade de recondução, além de ter sido observada em uma ocasião no âmbito da representação do Ministério Público - os ex-conselheiros José Adonis Callou de Araújo Sá (PRR-1) e Felipe Locke Cavalcanti (MP-SP) foram reconduzidos em 2009 -, é bastante observada no âmbito da representação oriunda do Congresso Nacional, que pode ser tida como afeta à participação da sociedade civil no Conselho. Com efeito, os ex-conselheiros Joaquim de Arruda Falcão e Marcelo Rossi Nobre, indicados respectivamente pelo Senado Federal e pela Câmara dos Deputados, foram reconduzidos, também respectivamente, em 2007 e 2010. Essa circunstância não chega, contudo, a dissimular as difíceis situações vivenciadas no Congresso para indicação de seus representantes. Assim, já por ocasião da primeira composição do CNJ, o Senado Federal foi instado, graças a uma manobra regimental, a votar a nomeação do ex-conselheiro Alexandre de Moraes (ex-secretário de Justiça do Estado de São Paulo), uma segunda vez, após seu nome ter sido rejeitado em uma primeira votação ${ }^{14}$. Novo imbróglio ocorreu na renovação dos membros do Conselho em 2007, quando a indicação da Câmara dos Deputados restou trancada por longos nove meses. Na ocasião, competiam pela nomeação cinco candidatos, conforme indicado no Quadro 3.

Ocorre que, por conta da aceitação da indicação de promotores de Justiça como representantes do Congresso Nacional no CNMP, o Partido Progressista ingressou com o Mandado de Segurança no 26.715, cuja liminar foi deferida pelo ministro Celso de Mello sobrestando o processo de nomeação dos conselheiros do $\mathrm{CNMP}^{15}$. Na decisão, o ministro reconheceu que a indicação efetuada poderia ensejar "uma possível descaracterização da colegialidade heterogênea, ínsita à própria composição e essencial à eficácia mesma do controle social que, por meio do CNMP, deve ser exercido, pela coletividade, sobre o Ministério Público" (ênfases no original). Na esteira dessa decisão, a Mesa Diretora da Câ- 
Quadro 3

Candidatos ao $\mathrm{CNJ}$

Vaga da Câmara dos Deputados em 2007

\begin{tabular}{|l|l|l|}
\hline Candidatos & \multicolumn{1}{|c|}{ Profissão } & \multicolumn{1}{|c|}{ Origem da Indicação } \\
\hline Marcelo Rossi Nobre & Advogado & PT, PMDB, PSDB e PR \\
\hline Helenilson Cunha Pontes & Advogado & DEM, PP, PPS, PSB e PMN \\
\hline $\begin{array}{l}\text { José Augusto Garcia de } \\
\text { Souza }\end{array}$ & $\begin{array}{l}\text { Defensor público e } \\
\text { professor da Universidade } \\
\text { Federal do Rio de Janeiro } \\
\text { (UFRJ) }\end{array}$ & PTB, PSC e PSOL \\
\hline Jorge Berg de Mendonça & Juiz do Trabalho 2009 & PV \\
\hline Michel Curi e Silva & Juiz estadual & PDT \\
\hline
\end{tabular}

Elaboração própria com base nas mesmas notícias referenciadas na Tabela 1 (ver nota 10).

mara decidiu suspender a eleição dos representantes que cabe à Câmara indicar tanto para o CNJ quanto para o CNMP. Ora, conforme a linha de raciocínio expressa na decisão liminar, as vagas destinadas aos dois cidadãos representantes da sociedade civil não poderiam ser preenchidas por nenhuma das profissões jurídicas já representadas nos conselhos. Por outro lado, como a Constituição exige que os indicados tenham "notável saber jurídico", torna-se quase inviável que a representação da sociedade civil seja feita por alguém estranho ao mundo das profissões jurídicas. Assim, caso prevalecesse a lógica da liminar, a vaga do $\mathrm{CNJ}$ teria que ser preenchida, obrigatoriamente, pelo defensor público José Augusto Garcia de Souza. Não foi, entretanto, o que aconteceu, pois o candidato indicado pela Câmara foi o advogado Marcelo Rossi Nobre, filho do ex-deputado federal Freitas Nobre. Na verdade, ele concorreu somente com o referido defensor público, já que, sem que o mérito do MS tenha sido julgado, os candidatos oriundos do Judiciário foram excluídos do processo pela Mesa da Câmara e o advogado Helenilson Cunha Pontes retirou sua candidatura. Posteriormente, o PP desistiu do MS e a questão por ele suscitada nunca mais foi enfrentada, seja por ocasião da recondução do conselheiro Marcelo Rossi Nobre em 2010, quando ele concorreu sozinho após a desistência do candidato Antonio Ernani Pedroso Calhão, seja nas indicações do Senado Federal em 2009 ou 2011. 


\section{Quadro 4}

Candidatos ao CNJ

Vaga do Senado Federal em 2009

\begin{tabular}{|l|l|l|}
\hline Candidatos & \multicolumn{1}{|c|}{ Profissão } & \multicolumn{1}{c|}{ Origem da indicação } \\
\hline André Ramos Tavares & $\begin{array}{l}\text { Professor da Universidade } \\
\text { de São Paulo (USP) }\end{array}$ & PDT \\
\hline $\begin{array}{l}\text { Antonio Ernani Pedroso } \\
\text { Calhão }\end{array}$ & $\begin{array}{l}\text { Professor da Universidade } \\
\text { Federal de Mato Grosso } \\
\text { (UFMT) e servidor } \\
\text { público do TRT-SP }\end{array}$ & Liderança da Minoria \\
\hline Erick Wilson Pereira & $\begin{array}{l}\text { Professor da Universidade } \\
\text { Federal do Rio Grande do } \\
\text { Norte (UFRN) e advogado }\end{array}$ & $\begin{array}{l}\text { Lideranças do Senado } \\
\text { Federal }\end{array}$ \\
\hline $\begin{array}{l}\text { Marcelo da Costa Pinto } \\
\text { Neves }\end{array}$ & $\begin{array}{l}\text { Professor da USP e } \\
\text { advogado }\end{array}$ & PT \\
\hline
\end{tabular}

Elaboração própria com base nas mesmas notícias referenciadas na Tabela 1.

Conquanto nada tenha sido dito acerca de uma possível sobrerrepresentação da classe advocatícia nas outras ocasiões, é curioso observar como o perfil dos postulantes à vaga do Senado Federal em 2009, consoante se verifica no Quadro 4, enfatiza suas inserções no espaço acadêmico. Na ocasião, o candidato Marcelo da Costa Pinto Neves derrotou, em segunda votação, o candidato Erick Wilson Pereira. Dois anos mais tarde, ele não teria o mesmo êxito em sua postulada recondução, já que seria derrotado pelo candidato Bruno Dantas Nascimento, consultor-geral legislativo do Senado Federal que até então estava exercendo mandato de conselheiro no CNMP. Curiosamente, o exercício da docência no Instituto de Educação Superior de Brasília (IESB) por Emmanoel Campelo de Souza Pereira, o mais recente conselheiro indicado pela Câmara dos Deputados, também foi avançado como uma evidência de seu saber jurídico. Na verdade, assim como o conselheiro Bruno Dantas Nascimento, Emmanoel Campelo de Souza Pereira também trabalhou previamente no Congresso, pois foi assessor parlamentar entre 2008 e 2011, além de ser sócio do escritório de advocacia de Erick Wilson Pereira, candidato derrotado para a vaga do Senado Federal em 2009. Que o universo dos indicados da sociedade civil tenha tamanha limitação é efetivamente algo surpreendente.

O exame dos diversos processos de indicação sinaliza para diferentes estratégias de ocupação das vagas. No âmbito da Justiça Estadual, o exercício prévio de atividades junto ao STF ou ao próprio CNJ é um ex- 
celente qualificador na competição. Por sua vez, na Justiça Federal, a participação prévia no movimento associativo dos juízes federais (e a tessitura de redes que ele possibilita) constitui uma excelente alavanca de candidaturas. Essa mesma participação é vista de forma ambígua na Justiça do Trabalho, pois o desencaixe entre as sugestões da Anamatra e o processo de escolha do TST não se traduz em uma recusa de indicações identificadas com o movimento associativo. Assim, tanto a ex-conselheira Morgana de Almeida Richa quanto o conselheiro José Lúcio Munhoz foram presidentes de associações regionais e, certamente, a partir desse lócus privilegiado, construíram redes que legitimaram suas postulações e indicações ${ }^{16}$.

Tabela 2

Quantitativo de Magistrados por Segmento

\begin{tabular}{l|c|c|c}
\hline Segmento & Primeiro Grau & Segundo Grau & Total \\
\hline Justiça Federal & 1.614 & 135 & 1.749 \\
Justiça do Trabalho & 2.612 & 505 & 3.117 \\
Justiça Estadual & 10.316 & 1.622 & 11.938 \\
\hline Total & 14.542 & 2.262 & 16.804 \\
\hline
\end{tabular}

Fonte: Relatório “Justiça em Números 2010”.

Quando examinadas à luz do quantitativo de magistrados existente em cada segmento (Tabela 2), essas diferentes estratégias ganham ainda mais sentido. O processo de construção da diferenciação capaz de evidenciar a potencialidade de um candidato que compete pela vaga do primeiro grau da Justiça Estadual, dada sua dimensão pouco mais de seis vezes maior do que, por exemplo, o universo da magistratura de primeiro grau da Justiça Federal, é muito mais complexo e difícil. Assim, ganha sentido que a diferenciação seja construída pela proximidade, ao invés de amplas redes a partir do movimento associativo, como seria o caso da Justiça Federal. Por sua vez, dada a dimensão quantitativa intermediária de seu universo, é possível intuir que esse processo no âmbito da Justiça do Trabalho navega entre as duas estratégias: proximidade e redes associativas.

Ora, na medida em que o modelo institucionalizado de competição entre múltiplos atores com interesses heterogêneos proporcionou diferentes capturas corporativas do Conselho, constata-se que a participação da sociedade civil no processo de controle social do Poder Judiciário produziu pífios resultados. Na verdade, essas diferentes capturas 
Quadro 5

Estratégias de Indicação

\begin{tabular}{|l|c|}
\hline Segmento & Estratégia \\
\hline Justiça Federal & Redes associativas \\
\hline Justiça do Trabalho & Redes associativas e proximidade com TST \\
\hline Justiça Estadual & Proximidade com STF e CNJ \\
\hline OAB & Arranjos corporativos (com equilíbrio federativo) \\
\hline Sociedade civil & Proximidade com mundo político \\
\hline
\end{tabular}

Elaboração própria.

corporativas alcançaram a própria representação da sociedade civil, cujos impasses no âmbito de seu processo de indicação proporcionaram, inclusive, um desencaixe temporal na composição do Conselho. Mais ainda, elas escamotearam outras importantes questões como a sub-representação de gênero presente em suas diferentes composições. Com efeito, entre 64 indicações realizadas, houve apenas seis mulheres. Ou seja, menos de $10 \%$ eram do gênero feminino. Está-se, portanto, diante de um conselho essencialmente masculino, como, aliás, são as cúpulas judiciais ${ }^{17}$. Pior: a participação feminina vem sendo reduzida ao longo das sucessivas gestões e, a partir de setembro de 2012, com a substituição da conselheira Eliana Calmon pelo ministro Francisco Falcão na Corregedoria Nacional de Justiça, o predomínio masculino será total. E, finalmente, com a substituição, saem de cena os protagonistas do confronto em torno da competência do Conselho havido entre seu presidente (Cezar Peluso) e a corregedora nacional (Eliana Calmon).

\section{COMPETÊNCIA: A CAPACIDADE DE CONTROLE}

Consoante definido no texto constitucional (art. 103-B, § 4ㅇ) , ao Conselho compete "o controle da atuação administrativa e financeira do Poder Judiciário e do cumprimento dos deveres funcionais dos juízes". Constata-se, assim, que o Conselho teria funções precípuas de controle, devendo zelar pela correta observância dos princípios constitucionais da administração pública e do Estatuto da Magistratura. Em outras palavras, de um lado, em respeito à autonomia dos tribunais, a gestão da organização judiciária, da judicatura (nomeação e seleção) e da avaliação de seu desempenho (promoção), matérias tradicionalmente afetadas aos conselhos judiciais, seriam regradas pelo CNJ apenas em uma perspectiva global, mediante o estabelecimento de diretri- 
zes para a totalidade do sistema, enquanto, de outro lado, era-lhe atribuída uma importante função de controle, que lhe facultava rever a atuação dos tribunais, inclusive e particularmente em sede disciplinar. Na esteira de tal perspectiva, o CNJ editou a Resolução no 135, de 13.07.2011, regulamentando o procedimento administrativo disciplinar relativo aos magistrados ${ }^{18}$, e com ela abriu mais uma polêmica com a AMB, que recorreu ao STF para impugnar a nova regulamentação.

Assim, com o ajuizamento da ADI no 4.638-DF, instaurou-se um intenso debate em torno da competência do CNJ. Como catalisadores das posições antagônicas, tinha-se, de um lado, o presidente do Conselho e, de outro lado, a corregedora nacional, cujas posições sustentavam, respectivamente, que as apurações de desvios deveriam ser apuradas localmente e que elas poderiam ser efetuadas diretamente pelo Conselho. O debate ganhou a imprensa e, após a corregedora nacional afirmar que havia "bandidos de toga"19, o presidente do Conselho capitaneou a edição, em setembro de 2011, de uma nota de esclarecimento por ele assinada com mais onze conselheiros repudiando tais acusações ${ }^{20}$. Poucos dias depois, os seis conselheiros representantes do Ministério Público, da OAB e da sociedade civil (Marcelo Nobre, Bruno Dantas, Wellington Saraiva, Gilberto Valente, Jorge Hélio Chaves e Jefferson Kravchychyn) publicariam um artigo conjunto na Folha de São Paulo enfatizando que o debate estaria fora de foco, pois "não se trata propriamente de recusar ou afirmar a competência originária do $\mathrm{CNJ}$ em matéria disciplinar (...), mas o que se deve discutir são formas procedimentais para que o funcionamento do Conselho represente também o fortalecimento das corregedorias dos tribunais." ${ }^{21}$ As evidências da fratura interna do Conselho, presentes na assinatura coletiva do artigo pela totalidade de seus membros não oriundos da magistratura, eram ainda mais explicitadas por seu presidente que, na mesma ocasião e no mesmo veículo, reafirmava sua posição original em favor das apurações locais ${ }^{22}$. Enfim, o debate fazia-se intenso e recrudesceria ainda em dois outros momentos: em dezembro de 2011, com a concessão monocrática de medida liminar pelo ministro relator Marco Aurélio em favor da inconstitucionalidade do regramento elaborado pelo CNJ e, em fevereiro de 2012, por ocasião de sua revogação pela estreita margem de seis votos a cinco pelo plenário do $\mathrm{STF}^{23}$.

Na verdade, conquanto a tensão entre autonomia e accountability estivesse sempre presente, já que a preservação da primeira era mobilizada para justificar a preferência regional enquanto o desejo de amplia- 
ção da segunda era utilizado em favor da preservação da competência do Conselho, esta discussão substantiva permaneceu ao largo do debate. $\mathrm{O}$ confronto ganhou ares pessoais, com destaque para questões conjunturais e corporativas, cujo maior impacto parece ter sido a capacidade de alterar a agenda do Conselho. Ou seja, embora seja intenso o poder presidencial para construir a agenda do Conselho, os conflitos internos de um judiciário múltiplo e heterogêneo, povoado de protagonistas com interesses diversos e por vezes conflitantes, teria aqui conseguido fazer com que sua capacidade de ditar a pauta tenha sido diluída.

\section{CONSTRUINDO UMA AGENDA}

Recentemente, o ex-conselheiro Joaquim de Arruda Falcão se manifestou de forma favorável a uma reforma do STF e da gestão dos tribunais que contemplasse um mandato de pelo menos cinco anos para o seu presidente, com o propósito de se evitar a "descontinuidade, quase insegurança jurídica e administrativa" oriunda de sua excessiva rotatividade. Para exemplificar seu argumento, ele sinaliza que "o presidente, em qualquer dos casos, conduz as prioridades do Supremo, mas, aqui, a pauta do ministro Jobim era uma; a da ministra Ellen Gracie, outra; a do ministro Gilmar Mendes, outra". Essa descontinuidade, na medida em que o presidente do STF também exerce a presidência do CNJ (art. 103-B, I, da Constituição), atingiria ainda as políticas administrativas. Exemplificativamente, ele aponta que a prioridade dada pelo ministro Jobim ao combate ao nepotismo e à implantação do teto salarial não foi acolhida na agenda de seus sucessores e, por conseguinte, na ausência de uma efetiva continuidade, "essas políticas perdem eficiência e se diluem no tempo diante da oposição dos magistrados contrários." 24 Essas mesmas preocupações com a construção da agenda e as possibilidades de resistência às mudanças já podiam ser encontradas no balanço da reforma no âmbito do Poder Judiciário realizado por Sadek (2010:15-16), para quem:

O peso das características individuais torna-se ainda mais relevante nos primeiros estágios de construção de uma instituição, quando é baixo o seu grau de institucionalização. Focalizando-se apenas a presidência do CNJ, notam-se contrastes entre os seus três presidentes, tanto nas prioridades quanto nos traços individuais. O primeiro, Nelson Jobim, encarregou-se, sobretudo, de criar o órgão; Ellen Gracie, em seguida, deu ênfase à informatização; Gilmar Mendes privilegiou a formulação 
de políticas de gestão e de defesa de direitos e garantias fundamentais. Tais prioridades e a maneira como são executadas repercutem de modo mais ou menos intenso no ritmo de institucionalização e no grau de fortalecimento do CNJ; no perfil e na imagem do Poder Judiciário; na dimensão e na intensidade de seus impactos e nas reações das demais instituições públicas. Dirigentes ativistas - como Jobim e Mendes -, ao mesmo tempo em que ampliam o número de iniciativas e de mudanças, também encontram maior resistência, quer devido à maior probabilidade de contrariarem interesses e privilégios, quer devido à vulnerabilidade decorrente de maior exposição.

Ambos os diagnósticos convergem para reconhecer a importância do poder de pauta da presidência, ainda que o ex-conselheiro Falcão assuma que isso ocorre por questões estruturais, ao passo que a professora Sadek argumenta que ele seria mais conjuntural e estaria atrelado ao baixo grau de institucionalização do Conselho. Em outras palavras, na segunda perspectiva, ainda que não fosse alterada a duração de dois anos do mandato da presidência, o poder de pauta diminuiria na proporção inversa ao grau de consolidação institucional do Conselho. Conquanto o argumento seja bastante plausível, ele parece desconsiderar a capacidade de pauta da presidência em um órgão cuja composição é tão heterogênea, fragmentada e, de certa forma, capturada por interesses segmentados de diferentes carreiras com distintas concepções da gestão judicial. Em outras palavras, a capacidade de pauta da presidência decorreria de condições estruturais, que não estariam vinculadas à excessiva rotatividade da presidência, mas à rotatividade da composição do Conselho tout court.

Assim sendo, na esteira da recomposição periódica do Conselho, sua agenda vem sendo revisitada por aquele que possui maior poder sobre sua construção: seu presidente. Embora os demais conselheiros tragam pautas próprias, por vezes construídas a partir de seus processos de indicação, é inegável que as presidências dos ministros Nelson Jobim, Ellen Gracie, Gilmar Mendes e Cezar Peluso formularam agendas específicas para o Conselho com correlatas estratégias de atuação que contribuíram para um contínuo processo de redesenho institucional. Nesse sentido, sua primeira presidência trouxe como pauta o processo de criação e institucionalização do próprio Conselho, adotando como estratégia a elaboração de diagnósticos e a aplicação de uma profilaxia corporativa mediante o enfrentamento das questões do nepotismo e do teto remuneratório. Por sua vez, a segunda presidência enfatizou o 
processo de informatização com o propósito de produzir bases quantitativas confiáveis por meio do projeto "Justiça em Números". Já a terceira presidência focou na elaboração de políticas de gestão e de defesa de direitos e garantias fundamentais, desenvolvendo um planejamento estratégico para o Poder Judiciário, além de uma forte ação regulatória expressa em mutirões e no enfrentamento do tema das escutas telefônicas. Tudo isso contribuiu para um desenho institucional cujas características sinalizam para a edificação de um sistema nacional, avaliável e hierárquico. Mais ainda, tudo isso proporcionou um revigoramento do protagonismo do Judiciário por conta de sua exposição na arena pública.

\section{Quadro 6}

Periodização da Pauta do CNJ

\begin{tabular}{|l|l|l|l|}
\hline Gestão & \multicolumn{1}{|c|}{ Pauta } & \multicolumn{1}{|c|}{ Estratégia } & Redesenho institucional \\
\hline Nelson Jobim & $\begin{array}{l}\text { Criação e } \\
\text { institucionalização }\end{array}$ & $\begin{array}{l}\text { Diagnóstico e } \\
\text { profilaxia } \\
\text { corporativa: } \\
\text { nepotismo e teto } \\
\text { remuneratório }\end{array}$ & $\begin{array}{l}\text { Sistema nacional } \\
\text { (confronto com os } \\
\text { Estaduais) }\end{array}$ \\
\hline Ellen Gracie & Informatização & $\begin{array}{l}\text { Produção de bases } \\
\text { quantitativas } \\
\text { confiáveis (Justiça } \\
\text { em Números) }\end{array}$ & $\begin{array}{l}\text { Sistema avaliável } \\
\text { (construção da métrica) }\end{array}$ \\
\hline Gilmar Mendes & $\begin{array}{l}\text { Políticas de gestão } \\
\text { e de defesa de } \\
\text { direitos e } \\
\text { garantias } \\
\text { fundamentais }\end{array}$ & $\begin{array}{l}\text { Planejamento } \\
\text { estratégico e ação } \\
\text { regulatória } \\
\text { (mutirões e escutas } \\
\text { telefônicas) }\end{array}$ & $\begin{array}{l}\text { (reforço de sua } \\
\text { verticalidade) }\end{array}$ \\
\hline Cezar Peluso & Controle & $\begin{array}{l}\text { Questões } \\
\text { procedimentais } \\
\text { (embate com OAB) } \\
\text { e regulação } \\
\text { corporativa } \\
\text { (LOMAN) }\end{array}$ & Sistema endógeno \\
\hline
\end{tabular}

Fonte: Sadek (2010:15-16) para as três primeiras gestões e elaboração própria para a quarta gestão.

O Quadro 6 sistematiza essa trajetória a partir das presidências do CNJ. Sem dúvida, o grande desafio da primeira presidência consistia justamente em sua implantação e na elaboração de uma dinâmica de funcionamento, como, aliás, pode-se perceber no balanço de seu primeiro ano de existência efetuado pelo ex-conselheiro Eduardo Kurtz Lorenzoni (2006). Os confrontos havidos diziam respeito à própria le- 
galidade do Conselho, uma vez que sua constitucionalidade foi diretamente questionada pela AMB por meio da ADI no 3.367-DF, que, em abril de 2005, foi julgada totalmente improcedente ${ }^{25}$. A estratégia dessa institucionalização deu-se por meio de uma profilaxia corporativa em torno dos temas: nepotismo e teto remuneratório, que foram enfrentados, respectivamente, nas simbólicas Resoluções no 7, de 18/10/2005, e no 14, de 21/3/2006. Em uma interessante reviravolta quanto à sua percepção inicial do Conselho, a AMB pleiteou judicialmente o reconhecimento da constitucionalidade desta última por meio da Ação Declaratória de Constitucionalidade no 12 , cuja procedência foi finalmente reconhecida pelo STF em agosto de $2008^{26}$. É, portanto, possível dizer que, quando o ministro Nelson Jobim encerrou seu mandato à frente do CNJ, o Conselho era uma realidade definitivamente inscrita no Poder Judiciário. Mas era ainda necessário enfrentar o universo de possibilidades que a novidade descortinava.

Em abril de 2006, após assumir a presidência do STF, a ministra Ellen Gracie tornou-se também presidente do CNJ e, com ela, a pauta do Conselho ganhou outros contornos, com ênfase na uniformização dos procedimentos de informática. Nesse sentido, destacam-se as Resoluções no 41, de 11/9/2007, e no 45, de 17/12/2007, que padronizam os endereços eletrônicos das páginas dos tribunais, bem como as Resoluções no 46 e no 47, ambas de 18/12/2007, que criam, respectivamente, as tabelas processuais unificadas e o Núcleo de Estatística e Gestão Estratégica do Poder Judiciário. Se a curta gestão precedente reafirmava o Judiciário como um sistema nacional, a segunda gestão criava as condições de possibilidades necessárias de elaboração de uma métrica que tornaria o sistema avaliável em uma perspectiva quantitativa. Consolidava-se, assim, o programa Justiça em Números, cujos dados se transformariam em importantes indicadores para o planejamento do Judiciário. É verdade que sob o risco de um desenfreado quantitativismo, cujo impacto sobre o ofício judicial ainda não foi adequadamente mensurado (Fragale Filho, 2007).

Uma nova guinada viria com a presidência do ministro Gilmar Mendes, cuja pauta se deslocaria para o desenvolvimento de políticas de gestão e de defesa de direitos e garantias fundamentais. Quanto àquelas, são simbólicas as Resoluções no 70, de 18/3/2009 (que trata do planejamento e gestão estratégica do Poder Judiciário), no 85, de 8/6/2009 (que versa sobre a comunicação social do Poder Judiciário) e no 99, de 24/11/2009 (que regulamenta o planejamento estratégico da tecnologia 
da informação e da comunicação no Poder Judiciário). Já a preocupação com o incremento de uma política de defesa de direitos e garantias fundamentais ganha guarida nas simbólicas Resoluções nํ59, de 9/9/2009 (que trata das escutas telefônicas), no 89, de 16/9/2009 (que institui os mutirões carcerários), no96, de 27/10/2009 (que estabelece o Projeto Começar de Novo) e no 101, de 15/12/2009 (que institui a política nacional de execuções das penas e medidas alternativas à prisão). Com isso, expressando preocupações específicas com o sistema carcerário e questões procedimentais na área penal, o Conselho enfatizava seu papel de articulador de um sistema nacional e avaliável, incorporando uma nova dimensão afeta à esfera profissional da magistratura, cujos componentes não funcionariam de forma isolada, já que integram um sistema hierárquico. É claro que essa mudança de foco não se traduz por um completo desprendimento em relação às questões presentes na pauta precedente. Ao contrário, os esforços de informática continuam presentes. Entretanto, eles perdem o protagonismo antes observado. Ao cabo, portanto, das três presidências, para além de uma hipertrofia de iniciativas diversas oriundas de cada presidência, tem-se também um desenho institucional para o Conselho cujas características sinalizam para a edificação de um sistema nacional, avaliável e hierárquico.

A ênfase dada à formulação de políticas não impede, contudo, que esse sistema patine em torno da difícil distinção entre as dimensões administrativa e judicial de seu controle. Conquanto suas decisões reafirmem que o controle dos atos judiciais constitui matéria estranha à sua competência, sua atuação disciplinar tem ampliado a zona cinzenta entre essas duas dimensões (Falcão, Lennertz e Rangel, 2009; Fragale Filho, 2010). Em outras palavras, como sua moldura de competências torna-se mais fluída, ele amplia seu espaço de atuação mediante a institucionalização de arenas de debate, como, por exemplo, o Fórum Nacional do Judiciário para Assistência à Saúde e o Fórum Nacional para Monitoramento e Resolução dos Conflitos Fundiários Rurais e Urbanos, os quais terminam por discutir, respectivamente, o processo de judicialização da saúde (Asensi, 2010) e a espinhosa questão agrária do país. Esse protagonismo, que açambarca, sob a chancela administrativa, uma ampla parcela da atuação judicial teria estado, contudo, ameaçado pela quarta composição do Conselho, sob a presidência do ministro Cezar Peluso.

Com efeito, o início da quarta presidência marca, mais uma vez, uma mudança na pauta do Conselho. Ela pode ser observada no confronto- 
quase simbólico - havido nos primeiros momentos com a OAB. Menos de dois meses após a mudança da presidência, o conflito se instalou em torno de uma questão procedimental relativa à possibilidade de manifestação do presidente do Conselho Federal da OAB durante a realização de um julgamento do $\mathrm{CNJ}$. Na ocasião, não obstante a tradição possibilitar uma intervenção quase ilimitada do presidente da $\mathrm{OAB}$, o ministro Peluso tentou limitar sua manifestação às regras procedimentais, que situam a referida manifestação após a sustentação oral dos advogados das partes e antes da dos votos dos conselheiros. Imediatamente, diversas seccionais manifestaram seu apoio ao presidente da $\mathrm{OAB}$, qualificando o ato do ministro Peluso como arbitrário, autoritário, cerceador e, sobretudo, descortês e desrespeitoso para com a advocacia brasileira. Outra circunstância, relembrada pelo ex-conselheiro Joaquim de Arruda Falcão, diz respeito ao julgamento de juízes pelo $\mathrm{CNJ}$, que, conquanto públicos durante a presidência do ministro Gilmar Mendes, deveriam ser apreciados, consoante o ministro Cezar Peluso, de forma sigilosa pelo Conselho. Enfim, conforme consignado pela $\mathrm{OAB}$ em seu Informativo Eletrônico, a nova pauta do CNJ consistiria em um processo de esvaziamento do próprio Conselho ${ }^{27}$. Sintomaticamente, de forma quase simultânea, o jornal O Estado de S. Paulo publicava o editorial "A crise do $\mathrm{CNJ}^{\mathrm{N}}$ ", no qual era dado destaque às ações do ministro Cezar Peluso, rememorando os confrontos antes narrados e sua defesa da tese de que a Corregedoria Nacional de Justiça deveria ter uma ação subsidiária àquela das corregedorias judiciais $^{28}$. Ou seja, a captura da pauta por uma perspectiva de autolimitação da ação do Conselho parecia ganhar corpo, definitivamente, com a proposta do ministro Cezar Peluso de alterar a composição do CNJ para incluir uma representação do Superior Tribunal Militar (STM) e outra do Tribunal Superior Eleitoral (TSE). Enfim, a pauta desenhada pela presidência do ministro Cezar Peluso parecia estar em consonância com o seu voto na ADI no 3.367-DF, quando ele indicou que:

Eu próprio jamais escondi oposição viva, menos à necessidade da ressurreição ou criação de um órgão incumbido do controle nacional da magistratura, do que ao perfil que se projetava ao Conselho e às prioridades de uma reforma que, a meu sentir, andava ao largo das duas mais candentes frustrações do sistema, a marginalização histórica das classes desfavorecidas no acesso à Jurisdição e a morosidade atávica dos processos. Não renuncio às minhas reservas cívicas, nem me retrato das críticas pré-jurídicas à extensão e à heterogeneidade da composição do Conselho. Mas isso não podia impedir-me, como meus sentimentos e predile- 
ções pessoais não me impediram nunca, em quatro lustros de ofício jurisdicional, de, atento à velha observação de Cardozo, ter "aberto os ouvidos sacerdotais ao apelo de outras vozes", ciente de que "as palavras mágicas e as encantações são fatais à nossa ciência quanto a quaisquer outras". Julgo a causa perante a Constituição da República ${ }^{29}$.

Em outras palavras, a pauta desenhada pela quarta presidência do CNJ parecia estar atrelada à própria questão do controle da magistratura e à sua forma necessariamente endógena de realização. Verificava-se, por conseguinte, um possível fechamento em torno de si mesmo, que, no limite, representaria uma recusa ao protagonismo construído a partir das pautas precedentes.

Curiosamente, a questão não seria sequer suscitada nos balanços realizados pelos ex-conselheiros cujo mandato se encerrou no primeiro semestre de 2011. Assim, a ex-conselheira Morgana de Almeida Richa reiterava que o CNJ "surgiu em 2005 como um divisor de águas para o modelo de Justiça brasileiro (...) e que a evidenciada dificuldade (de implantação) se agrega ao curto tempo de funcionamento do Conselho, já legitimado socialmente, mas ainda com um longo caminho a percorrer." ${ }^{30}$ Enquanto o ex-conselheiro José Adonis Callou de Araújo Sá ressaltava a necessidade de uma deliberação coletiva em relação aos projetos do Conselho (que seriam fruto de iniciativa dos juízes auxiliares) ${ }^{31}$, o ex-conselheiro Felipe Locke Cavalcanti destacava o seu papel criativo $^{32}$. Por sua vez, o ex-conselheiro Ives Gandra da Silva Martins Filho enfatizava que o CNJ deveria ser um órgão de coordenação do Poder Judiciário ${ }^{33}$, ao passo que o ex-conselheiro Nelson Tomaz Braga enfatizava a importância dos valores republicanos, lembrando "que esses princípios devem prevalecer sobre qualquer interesse pessoal ou político." ${ }^{34}$ De forma semelhante, o balanço efetuado pelo ministro Gilmar Mendes (2012:10-17) enfatiza a atuação de policy maker do Conselho, sem traçar um único comentário sobre sua atuação disciplinar. Em suma, todos eles parecem sinalizar para a importância republicana do CNJ, sem, entretanto, se dar conta de que sua pauta tem sido construída de dentro para fora, quase sempre ignorando as demandas de fora para dentro, e que seu processo decisório encontra-se prisioneiro das representações existentes em sua composição.

\section{PROCESSO DECISÓRIO: ESPECULANDO SOBRE SUAS POSSIBILIDADES}

Que o processo decisório seja prisioneiro das representações corporativas existentes na composição do CNJ é, no entanto, apenas uma das 
possíveis teorias existentes sobre comportamento judicial. Com efeito, Posner (2008:19) identifica nove modelos teóricos possíveis para examinar o comportamento judicial e indicar como os juízes decidem os casos não rotineiros: atitudinal, estratégico, sociológico, psicológico, econômico, organizacional, pragmático, fenomenológico e legalista. Em tais modelos, na medida em que se trata de efetivamente examinar, a partir de suas correspondentes hipóteses primárias, o comportamento dos juízes, privilegia-se o descritivo em detrimento do normativo. Em outras palavras, não se trata de examinar como os juízes deveriam comportar-se ou decidir em função do aparato normativo, mas de indagar sobre como eles efetivamente o fazem. Embora nenhum dos modelos teóricos possa ser tido como completa e exclusivamente satisfatório em sua capacidade explicativa, todos eles contribuem para uma mais robusta compreensão do comportamento judicial.

Conquanto seja inegável o intenso potencial explicativo de cada um desses nove modelos, eles não conheceram igual desenvolvimento no cenário nacional. Na verdade, os estudos desenvolvidos na área têm se concentrado na perspectiva atitudinal como evidencia, em especial, o debate travado nas páginas da Revista de Direito Administrativo (RDA) opondo as leituras de Prado e Türner (2010) e Arguelhes e Ribeiro (2010) ou ainda, em sentido mais amplo, quando se postula examinar tout court a influência dos ciclos políticos nas decisões judiciais (Ribeiro, Arguelhes e Peixoto, 2009). Em suma, o modelo atitudinal identifica um fator exógeno - usualmente, o partido político do presidente - que tornaria possível antecipar o comportamento judicial dos membros do Judiciário ${ }^{35}$. Realizando um paralelismo com tal problemática, especula-se aqui ser possível assumir que a mesma racionalidade decisória poderia ser emprestada aos membros do Conselho, adotando sua origem funcional como proxy. Ou seja, o Conselho estaria capturado pelas representações corporativas existentes em sua composição.

Assim, seu processo decisório sofreria a influência de seu desenho institucional e das possibilidades de elaboração de sua agenda a partir de suas representações corporativas. Com efeito, o impacto destes dois últimos sobre o primeiro dá-se em um duplo nível. Em um primeiro momento, como decorrência de suas competências, verifica-se que o Conselho oscila entre seu papel de formulador de policy e sua atuação de controle que lhe impõe um funcionamento aos moldes de um tribunal. Aliás, o impacto dessa oscilação ajuda a entender o problema já 
constatado no debate sobre a superposição das esferas administrativa e judicial. De qualquer sorte, quanto à dinâmica de funcionamento que aproxima o Conselho da lógica dos tribunais, as representações existentes em sua composição acabam por gerar um problema, com o forte risco de transformar seus membros em prisioneiros de suas representações. Por sua vez, em um segundo momento, essas mesmas representações terminam por ampliar o impacto do corporativismo sobre a agenda e o processo decisório.

Considerando tais circunstâncias, a Figura 1 traduz um exercício especulativo acerca do impacto dessas variáveis sobre o processo decisório em cada uma das gestões havidas no Conselho. Em seu início, na gestão do ministro Nelson Jobim, conquanto a pauta estivesse capturada pela magistratura em sua tentativa de definir os limites do Conselho, as decisões estariam mais abertas em virtude da ausência de uma parametrização prévia. Os debates em torno das questões do nepotismo e do teto remuneratório são bons exemplos dessa circunstância. Com efeito, o seu debate não se fez de "fora para dentro", mas ganhou corpo a partir da própria ação da magistratura, que chegou, inclusive, a judicializar a matéria levando-a ao STF. Quando tem início a gestão da ministra Ellen Gracie, na medida em que o Conselho parecia já estar institucionalizado e incorporado à arquitetura do Judiciário, verifica-se uma maior indefinição de pauta e uma cristalização das representações dos conselheiros. Assim, o grau de abertura da pauta seria maior, mas, por outro lado, as decisões parecem estar mais capturadas pelas representações. Já com o ministro Gilmar Mendes, ter-se-ia uma captura da pauta pela cúpula, retomando-se a abertura decisória em função da ênfase no caráter de policy maker emprestado ao Conselho. Finalmente, com o ministro Cezar Peluso, tem-se um deslocamento radical com a captura tanto da pauta quanto de suas decisões por conta de seu confronto interno, com as representações exacerbando-se, consoante indicam as manifestações coletivas dos membros não oriundos da magistratura. O exercício especulativo em relação à presidência do ministro Ayres Britto parece indicar uma inflexão para uma pauta mais aberta, ainda que as decisões possam permanecer capturadas pelas representações consolidadas ao cabo de quase uma década de funcionamento.

Na realidade, ainda que um exame do conteúdo decisório do Conselho seja necessário para corroborar o argumento aqui desenvolvido, podem-se imaginar quatro cenários ideais correspondentes a cada um dos quadrantes da figura. Assim, a combinação de uma pauta aberta 
Figura 1

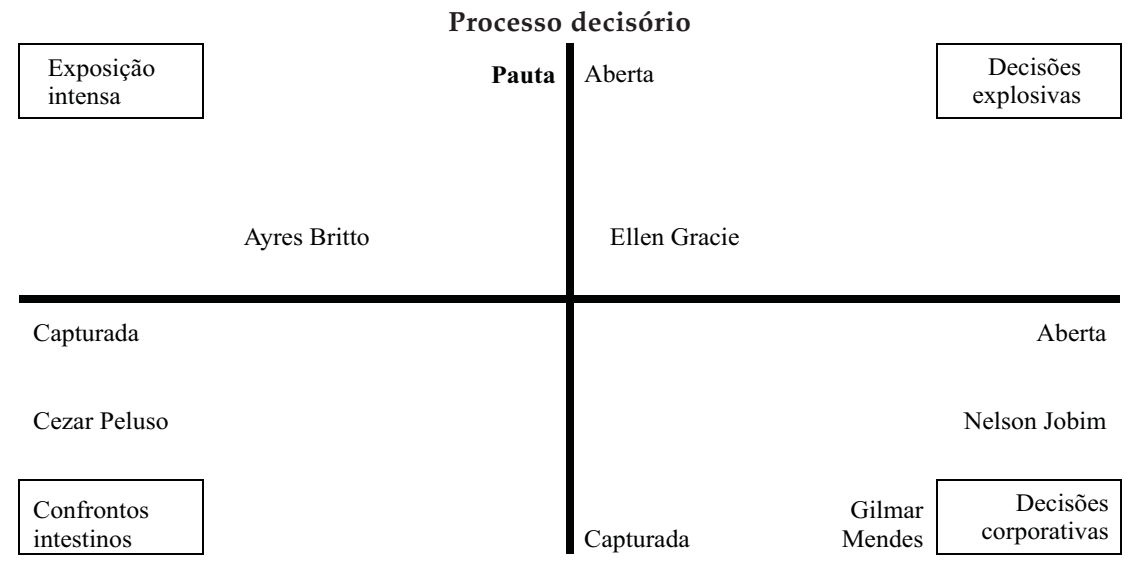

Elaboração própria.

com decisões capturadas resultaria em um processo decisório mais exposto, com maior interferência exógena na construção de sua agenda, ao passo que uma pauta capturada com decisões abertas possivelmente produziria decisões corporativas, mais preocupadas com as demandas oriundas do próprio sistema judicial, seja por parte de sua cúpula ou de sua base. Por outro lado, a captura da pauta e do processo decisório muito provavelmente exporia (talvez de forma traumática) os confrontos intestinos havidos no interior do Conselho, enquanto a existência de pauta e decisões abertas resultaria, quase certamente, em decisões explosivas. Aqui, o controle social poderia atingir seus patamares mais intensos, pois todas as possibilidades seriam permitidas, sem sofrerem as limitações impostas pela racionalidade representativa. Porém, enquanto cenários ideais, eles permanecem tão somente como um horizonte explicativo, que contribui para emprestar inteligibilidade à articulação examinada entre desenho institucional, construção de agenda e processo decisório no CNJ. No fundo, a ausência de uma análise mais circunstanciada e talvez processualmente restrita a uma carteira de processos não permite ir além dessa constatação: está-se diante de um possível horizonte explicativo que ainda requer muita escavação para que todas as suas possibilidades possam emergir.

\section{CONCLUSÃO}

O Conselho foi todo renovado, concluindo assim sua quarta gestão, cuja pauta parecia estar atrelada à ideia de controle, tanto de sua ação 
quanto da própria magistratura, traduzindo uma possível recusa do protagonismo alcançado ao longo das três primeiras gestões. A agenda do Conselho parecia se deslocar, de um lado, para questões procedimentais e, de outro lado, para o projeto de regulação corporativa expresso no debate em torno do futuro Estatuto da Magistratura. Entretanto, o embate interno, explicitado no confronto entre sua presidência e a corregedoria nacional, ainda que não tenha mudado a pauta (que continuou essencialmente focada na questão do controle), foi suficiente para modificar o antes previsível outcome de reforço das estruturas existentes.

O exercício analítico retrospectivo e a especulação prospectiva contribuem, sem dúvida, para entendermos os processos em curso e seu impacto sobre os desenhos institucionais que se perfilam para o próprio Conselho, o Poder Judiciário e a Magistratura brasileira. Estes processos, sistematizados no Quadro 7, parecem indicar que a arquitetura institucional concebida e adotada pelo conselho ao longo de seus anos iniciais pode estar vivenciando um amplo processo de mudança.

\section{Quadro 7}

Os Possíveis Desenhos Institucionais Oriundos da Ação do CNJ

\begin{tabular}{|l|l|l|}
\hline \multirow{2}{*}{ Instituições } & \multicolumn{2}{|c|}{ Gestões } \\
\cline { 2 - 3 } & $\begin{array}{c}\text { Nelson Jobim, Ellen Gracie e } \\
\text { Gilmar Mendes }\end{array}$ & \multicolumn{1}{c|}{ Cezar Peluso } \\
\hline Conselho & $\begin{array}{l}\text { Órgão concorrencial e, às } \\
\text { vezes, cooperativo. }\end{array}$ & Órgão subordinado. \\
\hline Poder Judiciário & $\begin{array}{l}\text { Sistema nacional, porém } \\
\text { pulverizado. }\end{array}$ & $\begin{array}{l}\text { Sistema hierarquizado, } \\
\text { administrativa e judicialmente. }\end{array}$ \\
\hline Magistratura & $\begin{array}{l}\text { Submetida ao controle social } \\
\text { externo, muito em função da } \\
\text { transparência. }\end{array}$ & $\begin{array}{l}\text { Submetida ao controle social } \\
\text { interno, especialmente em } \\
\text { função das características da } \\
\text { carreira. }\end{array}$ \\
\hline
\end{tabular}

Elaboração própria.

Estaria assim claro que, se as presidências iniciais sinalizavam para a instalação de um órgão concorrencial e, às vezes, cooperativo, sua mais recente configuração parecia se inclinar para o desenvolvimento de um órgão essencialmente subordinado à "verdadeira" cúpula do Judiciário nacional, instalada no STF. Por outro lado, essa nova circunstância parecia também sinalizar para a prevalência de um sistema hierarquizado administrativa e judicialmente em detrimento de um 
sistema nacional, ainda que pulverizado. Outra importante mudança pressentida, que afetaria o próprio papel da magistratura, na medida em que ela deixaria de estar submetida a um controle social externo, muito em função da transparência alcançada, para estar submetida a um controle social interno, no qual as corregedorias regionais desempenhariam um papel fundamental, desenhava-se no horizonte. Se nada disso aconteceu, foi porque a manutenção da pauta não se deu sem uma luta fratricida no interior do Conselho que não foi, entretanto, suficiente para trazer, como sempre fora postulado, o controle social externo para dentro de sua arena. Definitivamente, para além de mais uma reafirmação de sua derrota, a fratura imposta à redoma teria se limitado a fragilizar (e, eventualmente, desconstituir) arranjos locais (até hoje resistentes à estrutura de controle). Entretanto, o que nos resta responder é se essa fratura efetivamente tirou poder das redes locais ou terminou por, paradoxalmente, reforçar as cúpulas locais. Enfim, pior do que mudarem para continuar as mesmas, é quando as coisas mudam e parecem terminar por endossar, reforçar e ampliar o que tanto se quis um dia mudar.

(Recebido para publicação em novembro de 2012) (Reapresentado em julho de 2013) (Aprovado para publicação em outubro de 2013) 


\section{Roberto Fragale Filho}

\section{NOTAS}

1. Nas palavras do ministro-relator Cezar Peluso, "a instituição do Conselho, não apenas simboliza, mas também opera ligeira abertura das portas do Judiciário para que representantes da sociedade tomem parte no controle administrativo-financeiro e ético-disciplinar da atuação do Poder, robustecendo-lhe o caráter republicano e democrático". Ver http://redir.stf.jus.br/paginadorpub/paginador.jsp?docTP=AC\& docID=363371, acesso em 23/6/2012.

2. Conquanto, em português, seja possível utilizar as palavras responsabilidade ou responsabilização ou, ainda, a expressão "prestação de contas", tais termos não parecem ter o alcance e a abrangência presentes na palavra inglesa, razão pela qual optei por empregar o termo em inglês.

3. O exercício de confrontação entre perguntas fortes e respostas fracas é aqui reproduzido sob evidente influência do trabalho de Santos (2008, 2011a e 2011b).

4. Essa perspectiva encontra-se explicitamente indicada no voto do ministro relator Cezar Peluso na ADI n-3.367-DF, quando ele afirma que as prioridades da Reforma do Judiciário, nelas incluída a ressurreição ou criação de um órgão incumbido do controle nacional da magistratura, andavam ao largo das duas mais candentes frustrações do sistema, a marginalização histórica das classes desfavorecidas no acesso à jurisdição e a morosidade atávica dos processos. Ver nota 2 supra.

5. Ver os correspondentes currículos, respectivamente, em http://www.cnj.jus.br/sobre-o-cnj/composicao/composicao-atual?id=147 e http://www.cnj.jus.br/sobre-o-cnj/composicao/composicao-atual/jose-guilherme-vasi-werner, acesso em $24 / 6 / 2012$.

6. Ver o correspondente currículo em http://wwwh.cnj.jus.br/portalcnj/images/stories/conselheiros/novos/perfis/7.pdf, acesso em 24/6/2012.

7. Ver a galeria de presidentes da AJUFE em http://www.ajufe.org.br/portal/index.php?option $=$ com_content $\&$ view $=$ article $\&$ id $=1853 \&$ Itemid $=77$, acesso em 24/6/2012.

8. A jurisdição do TRF-1 engloba os Estados do Acre, Amapá, Amazonas, Bahia, Goiás, Maranhão, Mato Grosso, Minas Gerais, Pará, Piauí, Rondônia, Roraima e Tocantins, além do Distrito Federal.

9. Ver breves currículos em http://ww1.anamatra.org.br/003/00301015. asp?ttCD_CHAVE=71831, acesso em 24/6/2012.

10. Ver http://ww1.anamatra.org.br/003/00301015.asp?ttCD_CHAVE=94271, http://ww1.anamatra.org.br/003/00301015.asp?ttCD_CHAVE=77758, http://ww1.anamatra.org.br/005/00502001.asp?ttCD_CHAVE=22477 e http:/ / ww1.anamatra.org.br/005/00502001.asp?ttCD_CHAVE=28711\&btImprimir=SIM, acesso em 24/6/ 2012.

11. Ver http://www.tst.jus.br/ASCS/cnj2011/lista_juizesCNJ.pdf, acesso em $11 / 8 / 2011$.

12. Ver o correspondente currículo em http://www.cnj.jus.br/programas-dea-a-z/479-sobre-o-cnj/composicao/index.php?option=comãcontent\&view=article $\& \mathrm{id}=15930$ :jose-lucio-munhoz\&catid=479: composicao-atual $\&$ Itemid=1950, acesso em 24/6/2012. 
13. Ver http://www.cnmp.gov.br/portal/index.php?option=com_content\&view=article\&id=1005: proposta-regulamenta-a-indicacao-de-membro-do-mpu-para-compor-o-cnj\&catid=3:noticias-principal\&Itemid=146 e http:/ / www.cnmp.gov.br / portal $/$ index.php?option $=$ com_content $\&$ view $=$ article $\& i d=960: c n m p-r e j e i t a-$ proposta-de-rodizio-entre-ramos-do-mpu-no-cnj\&catid=3:noticias-principal\&Ite$\operatorname{mid}=198$, acesso em 24/6/2012.

14. Ver http://www12.senado.gov.br/noticias/materias/2005/05/24/nova-votacao-aprova-alexandre-de-moraes-para-o-cnj, acesso em 24/6/2012.

15. Cf. http://www.stf.jus.br/imprensa/pdf/ms26715.pdf, acesso em 11/8/2011.

16. Quanto à primeira, ver currículo resumido em http://www.cnj.jus.br/sobre-o-cnj/composicao/ composicao-atual?id=149 e, quanto ao segundo, ver nota 12 supra. Curiosamente, na eleição de 2007 para a direção da Anamatra, a ex-conselheira Morgana de Almeida Richa e o conselheiro José Lúcio Munhoz encabeçaram a derrotada chapa "Anamatra Democrática". Nesse sentido, suas correspondentes e sucessivas indicações para o TST podem também ser tidas como uma sinalização do referido tribunal contra a linha de ação adotada pela associação nacional. Ver http: / / ww1.anamatra.org.br/003/00301015.asp?ttCD_CHAVE=94373, acesso em $24 / 6 / 2012$.

17. Conquanto as cúpulas ainda sejam predominantemente masculinas, no dia internacional da mulher de 2012 (8/3/2012), o Consultor Jurídico publicou uma otimista reportagem indicando que, "em pouco tempo, (as) mulheres estarão na cúpula da Justiça". Ver http://www.conjur.com.br/2012-mar-08/aumenta-numero-mulheres-direito-sao-chegam-cupula, acesso em 24/6/2012.

18. Não se tratava, contudo, de matéria nova, pois o procedimento administrativo disciplinar relativo aos magistrados era antes regulado pela Resolução no 30, de 07.03.2007. Ver http://www.cnj.jus.br/images/stories/docs_cnj/resolucao/rescnj_30.pdf, acesso em 24/6/2012.

19. Ver http://www.estadao.com.br/noticias/nacional,fala-de-corregedora-sobre-bandido-de-toga-abre-crise-no-cnj,778177,0.htm, acesso em 24/6/2012.

20. Ver http://www.cnj.jus.br/noticias/cnj/16090:ministro-peluso-abre-sessao-plenaria-com-nota-de-esclarecimento, acesso em 24/6/2012.

21. Ver http://cnj.myclipp.inf.br/default.asp?smenu=\&dtlh=193248\&iABA= Not\%EDcias\&exp, acesso em 24/6/2012.

22. Ver http://cnj.myclipp.inf.br/default.asp?smenu=destaques\&dtlh=193240\& iABA=Notícias\&exp, acesso em 24/6/2012.

23. Ver http://www.stf.jus.br/portal/cms/verNoticiaDetalhe.asp?idConteudo= 196516 e http://www2.stf.jus.br/portalStfInternacional/cms/destaquesClipping. php?sigla=portalStfDestaqueãptãbr\&idConteudo=200022, acesso em 24/6/2012.

24. Ver "Vantagens e desvantagens", coluna de Merval Pereira no jornal O Globo, edição de 11/8/2011, p. 4. Disponível em http://cnj.myclipp.inf.br/default.asp?smenu= ultimas\&dth $=183967 \&$ iABA=Not\%EDcias\&exp=, acesso em 12/8/2011.

25. Ver http://redir.stf.jus.br/paginadorpub/paginador.jsp?docTP=AC\&docID $=363371$, acesso em 24/6/2012.

26. Ver http://redir.stf.jus.br/paginadorpub/paginador.jsp?docTP=AC\&docID $=606840$, acesso em 24/6/2012. 


\section{Roberto Fragale Filho}

27. Cf. http:/ / www.oab.org.br/noticia.asp?id=20401, acesso em 11/8/2011.

28. Cf. http://www.estadao.com.br/noticias/impresso,a-crise-do-cnj,598930,0.htm, acesso em 11/8/2011.

29. Ver nota 26.

30. Ver http://www.cnj.jus.br/entrevista-com-os-conselheiros/15080-morgana-richacnj-e-um-divisor-de-aguas-para-o-modelo-de-justica-brasileiro, acesso em $11 / 8 / 2011$.

31. Ver http://www.cnj.jus.br/entrevista-com-os-conselheiros/15079-jose-adoniscnj-deve-buscar-reducao-das-diferencas-no-poder-judiciario, acesso em 11/8/2011.

32. Ver http://www.cnj.jus.br/entrevista-com-os-conselheiros/15130-felipe-lockecnj-e-um-orgao-que-apresenta-visao-renovada-do-judiciario, acesso em 11 /8/2011.

33. Ver http://www.cnj.jus.br/entrevista-com-os-conselheiros/15137-ives-gandranocnj-tem-se-uma-visao-global-do-judiciario-seus-desafios-e-deficiencias, acesso em $11 / 8 / 2011$.

34. Ver http://www.cnj.jus.br/entrevista-com-os-conselheiros/15086-tomaz-bragacnj-avancara-no-desafio-de-dar-ao-pais-uma-prestacao-jurisdicional-de-qualidade, acesso em 11/8/2011.

35. Na maior parte da literatura, tem-se o judiciário federal norte-americano como referência. Como exemplo, ver Sunstein, Schkade e Ellman (2003). 


\section{REFERÊNCIAS BIBLIOGRÁFICAS}

ARGUELHES, Diego Werneck; RIBEIRO, Leandro Molhano. (2010), “Indicações Presidenciais para o Supremo Tribunal Federal e seus Fins Políticos: Uma Resposta a Mariana Prado e Cláudia Türner". Revista de Direito Administrativo, vol. 255, pp. 115-143.

ASENSI, Felipe Dutra. (2010), Indo Além da Judicialização. O Ministério Público e a Saúde no Brasil. Rio de Janeiro, Escola de Direito do Rio de Janeiro da Fundação Getulio Vargas, Centro de Justiça e Sociedade.

CONSELHO NACIONAL DE JUSTIÇA. (2011), Justiça em Números 2010. Brasília, CNJ. Disponível em http://www.cnj.jus.br/programas-de-a-a-z/eficiencia-modernizacao-e-transparencia/pj-justica-em-numeros/relatorios, acesso em 24/6/2012.

FALCÃO, Joaquim; LENNERTZ, Marcelo; RANGEL, Tânia Abrão. (2009), O Controle da Administração Judicial. Disponível em http://academico.direito-rio.fgv. $\mathrm{br} / \mathrm{ccmw} /$ images /1/1e/O_controle_da_administra\%C3\%A7\%C3\%A3o_judicial_ -_portugu\%C3\%AAs_-_M\%C3\%A9xico.pdf, acesso em 6/7/2010.

FRAGALE FILHO, Roberto. (2007), “Poder Judiciário: Os Riscos de uma Agenda Quantitativa", in J. N. de M. Coutinho; J. L. B. de Morais; L. L. Streck (orgs.), Estudos Constitucionais. Rio de Janeiro, Renovar.

. (2010), “Democratização dos Tribunais: Uma Nova Agenda para o Movimento Associativo". Trabalho apresentado no 7o Encontro da Associação Brasileira de Ciência Política (ABCP). Recife, 4-7 de agosto. Disponível em http: / / cienciapolitica.servicos.ws/abcp2010/arquivos/13_7_2010_17_44_32.pdf, acesso em 12/8/2011.

. (2011), “O Conselho Nacional de Justiça e seus Possíveis Impactos Institucionais”. Trabalho apresentado no 35 Encontro Anual da Anpocs. Caxambu, 24-28 de outubro. Disponível em http://www.anpocs.org.br/portal/35_encontro_gt/GT17/RobertoFragale.pdf, acesso em 24/6/2012.

GAROUPA, Nuno. (2011), O Governo da Justiça. Lisboa, Fundação Francisco Manuel dos Santos.

LORENZONI, Eduardo. (2006), “Um Ano de CNJ”. Revista ANPR Online, no 1. Disponível em http://www.anpr.org.br/portal/components/com_anpronline/media/ Artigo_UmAnoCNJ_EduardoKurtz.pdf, acesso em 29/12/2008.

MENDES, Gilmar. (2012), "As Contribuições do CNJ para o Judiciário Brasileiro". Justiça E Cidadania, julho, pp. 10-17.

POSNER, Richard. (2008), How Judges Think. Cambridge, MA, Harvard University Press.

PRADO, Mariana Prado; TÜRNER, Cláudia. (2010), “A Democracia e seu Impacto nas Nomeações das Agências Reguladoras e Ministros do STF". Revista de Direito Administrativo, vol. 250, pp. 27-74.

RIBEIRO, Leandro Molhano; ARGUELHES, Diego Werneck; PEIXOTO, Vítor de Moraes. (2009), “Processo Decisório, Judiciário e Políticas Públicas: Levando a Decisão Judicial a Sério". Trabalho apresentado no 33o Encontro Anual da Anpocs. Caxambu, 26-30 de outubro.

SADEK, Maria Tereza. (2010), "Poder Judiciário: Uma Nova Instituição". Cadernos Adenauer, ano XI, no 1, pp. 13-21.

DADOS - Revista de Ciências Sociais, Rio de Janeiro, vol. 56, no 4, 2013 


\section{Roberto Fragale Filho}

SANTOS, Boaventura de Sousa. (2008), "A Filosofia à Venda, a Douta Ignorância e a Aposta de Pascal". Revista Crítica de Ciências Sociais, no 80, pp. 11-43.

. (2011a), Para uma Revolução Democrática da Justiça. 3a ed. São Paulo, Cortez.

. (2011b), "A Encruzilhada da Universidade Europeia". Ensino Superior, 41. Disponível em http://www.boaventuradesousasantos.pt/media/A\%20encruzilhada\% 20da\%20Universidade\%20Europeia_Set11.pdf, acesso em 17/5/2012.

STRECK, Lenio Luiz. (2010), O que É Isto - Decido conforme Minha Consciência? Porto Alegre, Livraria do Advogado.

SUNSTEIN, Cass R.; SCHKADE, David; ELLMAN, Lisa Michelle. (2003), “Ideological Voting on Federal Courts of Appeals: A Preliminary Investigation". U Chicago Law \& Economics, Olin Working Paper No. 198; U Chicago, Public Law Working Paper No. 50; AEI-Brookings Joint Center Working Paper no 03-9. Disponível em: http: / / ssrn.com/abstract $=442480$ ou http: / / dx.doi.org/10.2139/ssrn.442480, acesso em $24 / 6 / 2012$. 


\begin{abstract}
Brazilian National Council of Justice: Institutional Design, Agenda-building, and Decision-making Process
\end{abstract}

After four administrations, a recent analysis of the work by the Brazilian National Council of Justice concludes that "the glass dome has cracked, since the inertia has been broken and taboos have been challenged", thereby injecting new energy into the judiciary system's leading role through its integration into the public arena. This break developed from an institutional design built under Constitutional Amendment 45/2004, which assigns an external oversight role to the Council, the contours of which have been constructed through its agenda-building, the composition of its membership, and the possibilities in its decision-making process. These three dimensions help explain the Council's role in the current architecture of the Brazilian judiciary and shed light on the debates over its scope of action.

Key words: National Council of Justice; external control; judges; institutional design; agenda-building; decision-making process

\title{
RÉSUMÉ
}

Le Conseil National de Justice Brésilien: Un Format Institutionnel, une Construction d'Agenda et un Processus de Décisions

$\mathrm{Au}$ bout de quatre gestions, un possible diagnostic du travail du Conseil National de Justice Brésilien souligne que "le vase a subi des fêlures, (car) l'inertie a été rompue et des tabous affrontés", ce qui a permis un renforcement de l'action du judiciaire et son insertion dans l'arène publique. Cette rupture serait tributaire d'un format institutionnel conçu par l'Amendement Constitutionnel 45/2004, qui octroie un rôle de contrôle (externe) au Conseil dont les contours sont définis à partir de l'élaboration de son agenda, de la composition de ses membres et des possibilités inclues dans son processus de décisions. La conjugaison de ces trois points permet de formuler une explication pour le rôle du conseil dans l'actuelle architecture du judiciaire et la compréhension des discussions actuelles sur la portée de son action.

Mots-clés: Conseil National de Justice Brésilien; contrôle externe; magistrature; format institutionnel; élaboration d'agenda; processus de décisions 